LIAMES 6 - pp. 101-108, Primavera 2006

Ana Carla Bruno

(Núcleo de Pesquisa em Ciências Humanas e Sociais Instituto Nacional de Pesquisas da Amazônia - INPA)

\title{
The Causative Construction in Waimiri Atroari
}

\begin{abstract}
In Waimiri Atroari, two kinds of causative construction may be observed: one in which causativization is morphologically marked with the suffix $-p \dot{i}$, generally with the semantic interpretation 'make somebody do something' or 'make/cause something without resistance' and the other with the 'let' reading, where the morpheme $-p \dot{p}$ does not occur.

KEYWORDS: Causative constructions; Waimiri Atroari language.

RESUMO: Em Waimiri Atroari são observados dois tipos de construções causativas: um em que a causativização é morfologicamente marcada com o sufixo - $p \dot{i}$, geralmente com a interpretação semântica "causar alguém fazer algo" ou "fazer algo sem resistência". O outro tipo de construção com uma leitura de "deixar/permitir que faça" onde o sufixo - pi, não ocorre.
\end{abstract}

PALAVRAS-CHAVE: Construções causativas; Língua Waimiri Atroari.

\section{INTRODUCTION}

This paper describes and analyzes the two types of causative construction in Waimiri Atroari': the causative construction with the - $p \dot{x}$ morpheme, having the 'make' reading, and the causative construction with the 'let' reading, in which the morpheme -pit, does not appear. The structure of the verb in Waimiri Atroari is basically prefix-stem-suffix. It can take a large set of different grammatical markers indicating person, tense-aspect-mood, negation, and causativization, as well as a specific derivational, suffix-tipi, used to form nouns.

${ }^{1}$ The Waimiri Atroari people, who call themselves kinja 'people' and whose language belongs to the Carib family, live today in an area in the northern part of the State of Amazonas and in the southern part of the State of Roraima. The total population is 1,113 individuals (PWA, Waimiri Atroari Program, November 2005). Linguistically, using Gildea's classification (1998) based on the morphosyntactic properties of each verbal system, the Waimiri Atroari language belongs to the set I system (nominative or inverse/split-S). Waimiri Atroari is a chronically underdescribed language. There are few linguistic studies on Waimiri Atroari, most of them being phonological sketches (Hill and Hill 1985; Lacerda 1991, and Bruno 2003, 2004, 2005). 
Table 1 - Structure of Waimiri Atroari Verbs

\begin{tabular}{|c|c|c|c|c|c|c|c|}
\hline \multicolumn{3}{|c|}{ Case marking } & \multirow{2}{*}{ ROOT } & \multirow{2}{*}{$\begin{array}{l}\text { Verbalizer } \\
\text { Nominalizer }\end{array}$} & \multirow{2}{*}{$\begin{array}{l}\text { Causative } \\
\text { Negation } \\
\text { Imperative } \\
\text { Desiderative }\end{array}$} & \multicolumn{2}{|c|}{ TAM } \\
\hline \multicolumn{2}{|c|}{ Clitic } & Prefix & & & & Tense-aspect-- & $\begin{array}{l}\text { Interrogative } \\
\text { clitic }\end{array}$ \\
\hline \multirow{3}{*}{ see } & $\begin{array}{l}a \mathrm{a}= \\
1 \mathrm{O}\end{array}$ & & $\begin{array}{l}- \text { ini- } \\
\text { see }\end{array}$ & & $\begin{array}{c}-\mathrm{pi} \\
-\mathrm{CAU}\end{array}$ & $\begin{array}{c}\text {-pia } \\
\text { IMD.PAST }\end{array}$ & \\
\hline & & $\begin{array}{l}\mathrm{h}- \\
1 \mathrm{~A}\end{array}$ & $\begin{array}{l}- \text { ini- } \\
\text { see }\end{array}$ & & $\begin{array}{c}\text {-pi } \\
\text {-CAUS }\end{array}$ & $\begin{array}{c}\text {-pia } \\
\text { IMD.PAST }\end{array}$ & \\
\hline & & $\begin{array}{l}\mathrm{m}- \\
2 \mathrm{~A}\end{array}$ & $\begin{array}{l}- \text { ini- } \\
\text { see }\end{array}$ & & & $\begin{array}{c}\text {-pi } \\
\text { IMD.PAST }\end{array}$ & $\begin{array}{l}=\mathrm{e}^{\prime} \\
\text { INT }\end{array}$ \\
\hline \multirow{2}{*}{ vomit } & $\begin{array}{l}a \mathrm{a}= \\
1 \mathrm{O}\end{array}$ & & $\begin{array}{l}\text {-wen- } \\
\text { vomit }\end{array}$ & $\begin{array}{c}\text {-ta } \\
\text { VERBL }\end{array}$ & $\begin{array}{c}-\mathrm{pi} \\
\text { CAUS }\end{array}$ & $\begin{array}{c}\text {-pia } \\
\text { IMD.PAST }\end{array}$ & \\
\hline & & $\begin{array}{l}\text { hu- } \\
1 \mathrm{~A}\end{array}$ & $\begin{array}{l}\text {-wen- } \\
\text { vomit }\end{array}$ & $\begin{array}{c}\text {-ta } \\
\text { VERBL }\end{array}$ & $\begin{array}{c}-\mathrm{pi} \\
\text { CAUS }\end{array}$ & $\begin{array}{c}\text {-pia } \\
\text { IMD.PAST }\end{array}$ & \\
\hline
\end{tabular}

The organization of the paper is as follows: Section 1 gives a short background on the Waimiri Atroari language; Section 2 provides a description and analysis of causative constructions in this language and, in addition, gives some examples of the particle $i \boldsymbol{a}$ that marks agentivity. Some remaining issues are discussed in the conclusion in section 3 .

\section{DESCRIPTION AND ANALYSIS}

In Waimiri Atroari, two kinds of causative construction may be observed. In the first

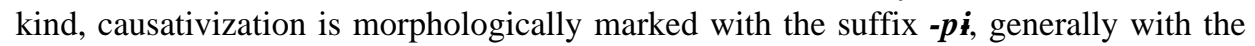
semantic meaning 'make somebody do something' or 'cause something without resistance'. The second kind has the 'let' reading, and the morpheme -pi does not occur.

\subsection{The Construction with the 'made' reading}

In this kind of construction, Waimiri Atroari allows two possible structures, one of them in which the causative morpheme appears on the lexicalized made/cause verb, as in examples (1) to (4), and the other structure in which this lexicalized verb does not appear, as in the examples (5) to (13).
(1) Aa Kaina $\mathrm{h}$ - ari - pi - pia
1PRO Kaina 1S-tell-CAUS-IMD.PAST
kiriwu
ini-se
snake see-PURP.MOT

'I told/dictated Kaina to see the snake'. 


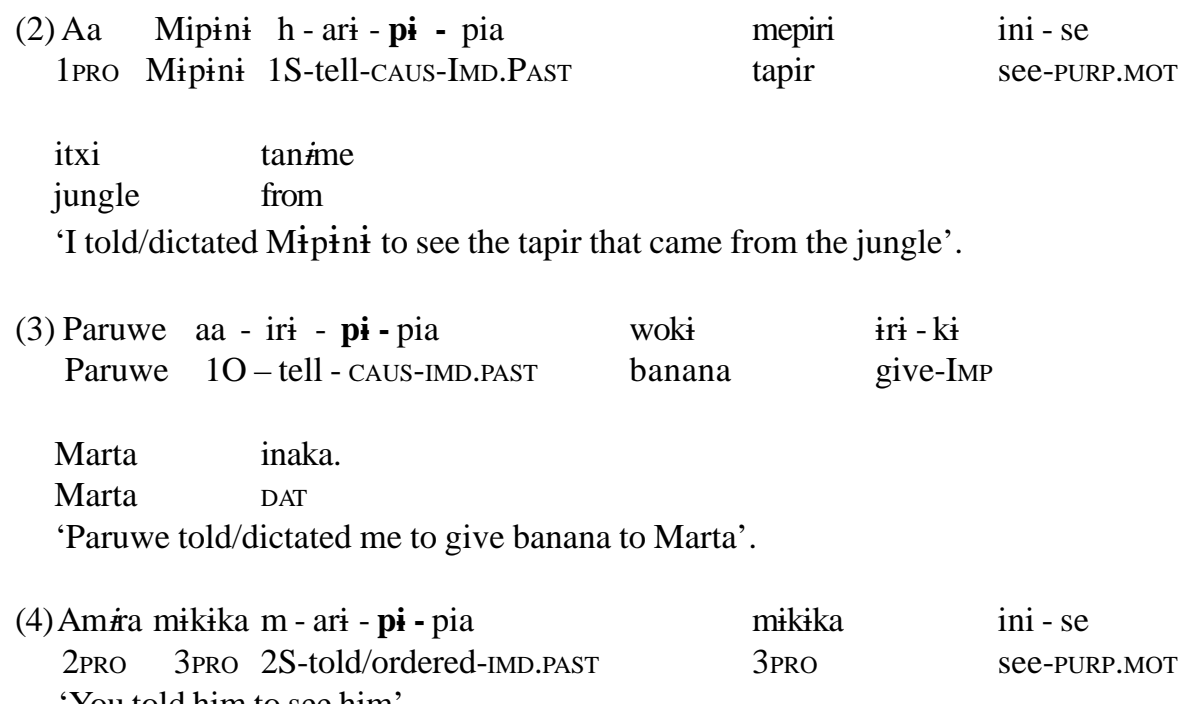

'You told him to see him'.

(5) Amira ram ka mu-wen - tah - pi - pia 2PRO 2PART 3PRO 2S - threw up-VERBL-CAUS-IMD.PAST

'You made him throw up'.

(6) ka ram a - wen - tah - pi - pia

3PRO 2PART $2 \mathrm{O}$-threw up-VERBL-CAUS-IMD.PAST

'She/he made you throw up'.

(7) $\mathrm{ki} \mathrm{ka} \mathrm{ram}$ ka hu - mini - tah - pi - pia 1+2PRO 2PART 3PRO 1+2S-bleed-VERBL-CAUS-IMD.PAST

'You made him bleed'.

(8) $\mathrm{Ka} \quad$ k-yeepitxah - pi - pia

3PRO 1+2O-laugh-CAUS-IMD.PAST

'She/he made us laugh'.

(9) $\mathrm{Ka} \quad$ ram $\quad$ a-irima - $\mathbf{p i}$ - piani

3PRO 2PART $2 \mathrm{O}$-rest- CAUS-REC.PAST

'He made you rest'.

(10) Ka ram aa - kitah - pi - pia

3PRO 2PART 1O-shout-CAUS-IMD.PAST

'He made me shout'. 
$\begin{array}{lllll}\text { (11) Ka } & \text { ram } & \text { aa - ima - pi - pia } & \text { sina } & \text { kaka } \\ \text { 3PRO } & \text { 2PART } & \text { 1O-jump-CAUS-IMD.PAST } & \text { water } & \text { LOC }\end{array}$

'He made me jump in the water'.

(12) Kika Joanico hi - ma - pi - pia sina kaka.

1+2PRO Joanico 1+2s-jump-CAUS-IMD.PAST water LOC

'We made Joanico jump in the water'.

(13) Aa ram ka hu-pakah-pi - pa.

1 PRO 2PART 3PRO 1s-wake up-CAUS-REM.PAST

'I made him wake up'.

(14) Aa ram Kaina ia kiriwu h-ini-pi-pia

1 PRO 2PART Kaina AGT.PART snake 1s-see-CAUS-IMD.PAST

'I made Kaina see the snake'.

In the cases described above, we may note that when an intransitive verb, such as shout, rest, wake up, laugh, jump, threw up, and bleed, takes the causative, it seems to behave as a transitive verb having the following structure: V[Intr +Caus [ S O]]. Moreover, it may be observed in example (14) that when we have a CAUSEE, it is optionally followed by the agentivity particle ia (Meira 1999, Gildea, 1998, Tavares 1995).

Interestingly, in example (1), Aa Kaina haripipia [PRO kiriwu inise], we can observe a kind of control structure: Kaina can control the subject PRO of the complement. As a result, the old subject Kaina becomes an indirect object by raising. However, as in Japanese, in Waimiri Atroari the causers (as initiators of the events) are generated in the SPEC of the Event Phrase Tree (Harley, 1995). To illustrate this assumption, we decided to use the Event Phrase as suggested by Harley (1995).

In the structure illustrated in (b) above, $A a$ is the CAUSER, having the highest position in the hierarchy of the tree; that is, it was generated in the first Event Phrase. Kaina is the CAUSEE. The lexicalized cause/made verb was put in the second Event Phrase and finally the VP kiriwu inise is what the causee has to do.

a)

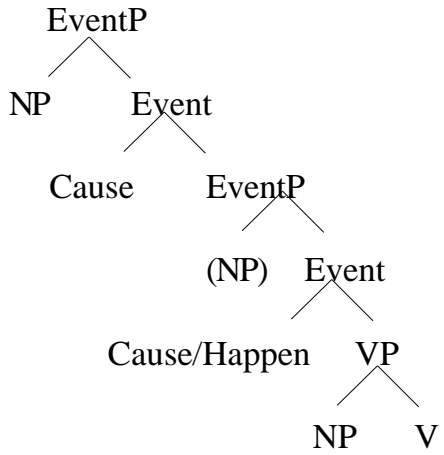

b) EventP

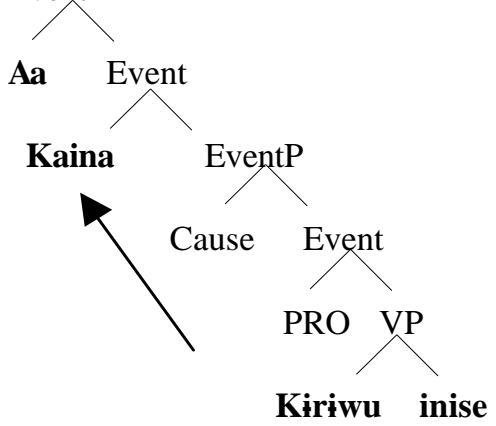




\subsection{The Construction with the 'let' reading}

One of the differences between the 'make' and 'let' causative is that in the 'let' causative construction people are not forced to do something, and as a result this does not imply an order and its accomplishment. Therefore, in this case, we observe a particle tre'me, that is used when we permit or order somebody to do something but do not know if the person will do it. In this sense, we agree with Levin (2000) when she argues that 'causative and accomplishment are independent notions'. Consequently, in (15) below it is not necessarily true that the person will learn how to make a ceramic pan, nor is it necessarily true in (16) that the person will leave to hunt.

(15) Aa

$$
\text { wo'nj-e'me } \quad \mathrm{h} \text { - aminjaki - piani } \quad \mathrm{a} \text {-wenpa - tipah }
$$

$1 \mathrm{PRO}$

$$
\text { clay - VAL 1s-permit/let-REC.PAST 2O-learn - in order }
$$

tre'me

$$
\text { tiruwa kapri piki }
$$

PART pan make how

'I permitted/let you tamper in the clay to learn how to make a ceramic pan'.

(16) Aa

$$
\text { ka m - injaki - piani }
$$

1PRO EVID $2 \mathrm{O}$ - permit/let-REC.PAST
'I permitted/let you to leave to hunt'.

witi ipi - na tre'me

The other difference between the two types of constructions is that in the 'let reading' construction we do not have the causative morpheme -pi. On the other hand, we cannot assume that the particle tre'me is a particularity of the 'let reading' causative, because it may occur in examples such as the one below:

$$
\begin{aligned}
& \text { (17) Aa k - aa - piani mariba taka a - iwapi - tri } \\
& \text { 1PRO } 2 \mathrm{O} \text { - take-REC.PAST party/song DIR 2O-sing - ? } \\
& \text { piki - a - wenpa - tipa tre'me } \\
& \text { how } 2 \mathrm{O} \text {-learn - in order PART }
\end{aligned}
$$

In this sentence, as in (15) and (16), it is not necessarily true that the person will learn how to sing.

\subsection{The Agentivity Particle ia}

In relation to the agentivity particle $i a$, it is interesting to observe that the particle is not necessarily related to the causative construction. The examples below will demonstrate in what kind of situation it may appear. 
(18) ipaikipa naminja ia $\mathrm{t}$ - iika - hkipa wikir-eme ni - tam-pia After dog AGT.PART REFLX-bite-after man-DEV 3s-cry-IMD.PAST 'After the dog bit the man, he cried'.

$\begin{array}{cllll}\text { (19) naminja } & \text { ia } & \mathrm{t} \text { - iika - hkipa } & \text { wikiri } & \mathrm{ni} \text { - tam - pia } \\ \text { Dog } & \text { AGT.PART } & \text { REFLX-bite-after } & \text { man } & 3 \mathrm{~s}-\text { cry - IMD.PAST. }\end{array}$

'After the dog bit the man, he cried'.

(20) naminja ia $\quad t$ - iika - si-pesa ram txi-pia tipotxe. DogaGt. PART REFLX-bite-?-in time 2PART go-IMD.PAST fast/quick 'In time to be bitten by the dog, he went quickly'.

(21) Amira ram aa - papa ia timere wo m-ini-pa 2PRO 2PART 1POS-father AGT.PART jaguar kill 2S-see-REM.PAST

'You saw my father kill the jaguar' or 'You saw the death of the jaguar by my father'.

(22) Ka ram aa - mama ia sanja iahkwa ini-piani 3PRO 2PART 1POS-mother AGT.PART manioc flour make see-REC.PAST 'He saw my mother make manioc flour'.

(23) Aa ram naminja ia $\mathrm{k}$-eme iika $\mathrm{h}$-ini-piya 1 PRO 2PART dog AGT.PART 3PRO-DEV bite 3s-see-IMD.PAST 'I saw the dog bite him'.

$\begin{array}{ccllll}\text { (24) Aa } & \text { ram witi } & \text { pis - ani } & \text { itxi } & \text { ta } & \text { kiriwu huwa } \\ \text { 1PRO } & \text { 2PART meat } & \text { look for-T/ASP } & \text { jungle } & \text { LOC } & \text { snake }\end{array}$

ia aa - iika - paiki

AGT.PART 10 - bite - after

'I was hunting when the snake bit me'.

\begin{tabular}{|c|c|c|c|c|}
\hline (25) $\mathrm{k}$ - eme & aa & timere & $w u-s \dot{f}$ & na \\
\hline 3PRO-DEV & AGT.PART & jaguar & kill-DESID & $\mathrm{COP}$ \\
\hline
\end{tabular}

As may be observed, the particle $\boldsymbol{i} \boldsymbol{a}$ has an independent behavior. Therefore, we assume that its occurrence is not obligatory in the causative construction. It will appear only when it is necessary to identify the CAUSEE as the agent of the structure. As a result, we have the following structure: [S CAUSEE (ia) $\mathrm{O} \mathrm{V}_{\text {-caus }}$ ], as see, in example (14).

Another interesting aspect of the particle $\boldsymbol{i} \boldsymbol{a}$ is related to the notion of agency, but this is a topic for further research. According to Mithun (1991:516), the prototypical agent is the 'participant which performs effects, instigates, or controls the situation denoted by the predicate'. Mithun's treatment of agentiveness as performance/instigation and control/ volitionality is not perfectly adequate for Waimiri Atroari. 


\section{CONCLUSION}

In this paper, two types of causative construction in Waimiri Atroari were described, the causative with the 'made' reading and the causative with the 'let' reading. The construction having the 'made reading' takes the causative morpheme - $p \dot{x}$ and implies that an order given by the CAUSER was realized by the CAUSEE. However, the construction having the 'let' reading does not take the morpheme - $\boldsymbol{p} \boldsymbol{i}$, and, unlike the causative 'made' reading, the event does not need to be accomplished (see table 2 below). In addition, it was observed that all transitive verbs could take the morpheme - $\boldsymbol{p} \boldsymbol{i}$.

In the data, we did not find examples in which the particle $i \boldsymbol{a}$ co-occurs with the lexicalized causative verb tell/dictate. Finally, an aspect that we consider needs more analysis is the causative construction with the 'let reading', as we have found few examples of this kind of construction.

Table 2- Summary of the causative construction

\begin{tabular}{|c|c|}
\hline Causative with the 'made reading' & Causative with the 'let reading' \\
\hline $\mathrm{S} \mathrm{V}_{\text {-caus }} \mathrm{O}$ (examples 5-13) & $\mathrm{S} \mathrm{O} \mathrm{V}_{\text {let reading }} \mathrm{CP}$ (examples 15 and 16) \\
\hline $\mathrm{S}$ CAUSEE (ia) $\mathrm{O} \mathrm{V}_{\text {-caus }}$ (example 14) & \\
\hline S CAUSEE $\mathrm{V}_{\text {1-caus }} \mathrm{O}$ V2 (examples 1-4) & \\
\hline
\end{tabular}

\section{REFERENCES}

BRUNO, Ana Carla. (2003). Waimiri Atroari Grammar: Some Phonological, Morphological, and Syntatic Aspects. PhD Dissertation. Tucson: University of Arizona.

.(2004). Reduplicação em Waimiri Atroari. Amerindie: IRD. Vol. especial sobre línguas Carib.

.(2005). Waimiri Atroari Pronominal System. In Stella Telles (org.). Coletânea Axéuvyru. Recife: Editora Universitária UFPE

GILDEA, Spike. (1998). On Reconstructing Grammar: Comparative Cariban Morphosyntax. Oxford Studies in Anthropological Linguistics 18. Oxford: Oxford: University Press.

HARLEY, Heidi. (1995). SASE Bizarre: The Structure of Japanese Causative. MIT. 13p. Ms.

HILL, Joseph and HILL, Tamara. (1985). Phonological Sketch of Waimiri Atroari (Cariban). Unpublished Manuscript. Missão Evangélica da Amazônia.

LACERDA, Edith Maria Neves. (1991). Waimiri Atroari: Observações Lingüísticas. Unpublished Manuscript. Manaus, Brazil: Programa Waimiri Atroari.

LEVIN, Beth. (2000). Aspect, Lexical Semantic Representation, and Argument Expression. Talk given at Linguistic Colloquium at University of Arizona, Tucson. (Handout). 
MEIRA, Sergio. (1999). A Grammar of Tiriyó. Doctoral Thesis, Rice University, Houston.

MITHUN, Marianne. (1991). Active/Agentive case marking and its motivations. Language 67: 510-546.

TAVARES, Petronila. (1995). Causation in Wayana (Cariban). Rice University. 6p. Ms.

\section{Abbreviation}

$\begin{array}{llll}\text { Agt.Part } & \text { Agentivity particle } & \text { Imd. Past } & \text { Immediate Past } \\ \text { Caus } & \text { Causative } & \text { Imp } & \text { Imperative } \\ \text { Dat } & \text { Dative } & \text { Loc } & \text { Locative } \\ \text { Desid } & \text { Desiderative } & \text { Neg } & \text { Negation } \\ \text { Dev } & \text { Devaluative } & \text { O } & \text { Objetc } \\ \text { Dir } & \text { Directional particle } & \text { Pro } & \text { Pronoum } \\ \text { Purp. Mot } & \text { Motion Purpose } & \text { Verbl } & \text { Verbalizer } \\ \text { Rec. Past } & \text { Recent Past } & 1 \text { Pos } & \text { 1 possessive } \\ \text { Rem. Past } & \text { Remote Past } & 1 & \text { First Singular } \\ \text { Reflx } & \text { Reflexive } & 2 & \text { Sing/Plural } \\ \text { S } & \text { Subject } & 3 & \text { Sing/Plural } \\ \text { T/Asp } & \text { Tense/Aspect } & 1+2 & \text { Dual incl } \\ \text { Val } & \text { Valuative } & 2 \text { part } & \text { Second position particle }\end{array}$

Recebido: $10 / 05 / 2006$

Aceito: 30/11/2006 